УДК $537.868+621.317 .784$

\title{
ВЛИЯНИЕ ФЕРРИМАГНИТНОГО РЕЗОНАНСА НА ПРЕОБРАЗОВАНИЕ ЭЛЕКТРОМАГНИТНОЙ ЭНЕРГИИ В МЕХАНИЧЕСКУЮ
}

\author{
МАРТЫНЕНКО Л. Г. ${ }^{1}$, КОМАРОВА А. Л. ${ }^{2}$, МАЛИЧЕНКО В. В. ${ }^{1}$ \\ ${ }^{1}$ Харьковский торгово-экономический институт \\ Киевского начионального торгово-экономического университета, \\ Украина, Харьков, пер. О. Яроша, 8 \\ ${ }^{2}$ Украинский государственный университет железнодорожного транспорта, \\ Украина, Харьков, пл. Феербаха, 7
}

\begin{abstract}
Аннотация. Методом физического моделирования в нулевом приближении в работе получен алгоритм вычисления силы, с которой электромагнитная волна, распространяющаяся в прямоугольном волноводе, действует на ферритовый шар, помещенный в постоянное магнитное поле. Исследована зависимость силы от величины магнитной напряженности вблизи ферримагнитного резонанса. Теоретические результаты вычислений сопоставлены с экспериментальными. При резонансе электромагнитная волна мощностью 10 Вт и длиной 3,2 см действует на ферритовый шар диаметром 3,55 мм с силой, равной $6 \pm 0,5$ мкН. Данной силы достаточно для вращения подвесной системы образцового пондеромоторного ваттметра, закрепленной с двух концов с помощью растяжек или кернов. Это позволяет разработать высокоточные ваттметры СВЧ с достаточной механической прочностью и надежностью для промышленного применения.
\end{abstract}

Ключевые слова: электромагнитная энергия; ферримагнетики; резонанс; преобразование; пондеромоторный ваттметр

\section{ПОСТАНОВКА ПРОБЛЕМЫ В ОБЩЕМ ВИДЕ}

Электромагнитная энергия СВЧ используется в различных областях науки и техники: ускорители элементарных частиц, системы термоядерного синтеза, нагрев и обработка материалов и изделий в пищевой промышленности, радиолокации, телекоммуникации [1], медицине [2] и др. [3].

Рациональное использование энергии СВЧ невозможно без надежных и точных измерительных устройств. Одним из основных параметров электромагнитной энергии, который необходимо контролировать при ее использовании, является мощность.
В настоящее время для измерения мощности электромагнитной энергии СВЧ в промышленных условиях используются ваттметры, например DPM 5000-EX фирмы «Bird Electronic Corporation», USA [4], R\&S®NRP2 фирмы «Rohde \& Schwarz» [5], M3-56, МК3-71 компании «Меридиан» [6]. Погрешность измерения проходящей от генератора до нагрузки мощности этими ваттметрами составляет 4-5\% без учета погрешности рассогласования и погрешности дополнительных переходов.

Известны образцовые пондеромоторные ваттметры, максимально приближенные к эталонам, которые имеют погрешность измерения проходящей от генератора до нагрузки мощности равную $0,2 \%$ [7]. Использование этих ваттметров в промышленных условиях 


\section{БИБЛИОГРАФИЧЕСКИЙ СПИСОК}

1. Ребров С. И. Научно-технические статьи С. И. Реброва / С. И. Ребров // Электронная техника. Сер. 1. СВЧ-техника. - 2009. - № 1. - С. 31-70. - Режим доступа : http://elibrary.ru/item.asp?id=14864398.

2. Alsuhaim H. S. Effects of low power microwaves at $1.8,2.1$, and $2.3 \mathrm{GHz}$ on L-lactic dehydrogenase and Glutathione peroxidase enzymes / Hamd S. Alsuhaim, Vuk Vojisavljevic, Elena Pirogova // J. Electromagnetic Waves Applications. - 2014. - Vol. 28, No. 14. - P. 1726-1735. — DOI : 10.1080/09205071.2014.934924.

3. Ka M.-H. Limiting accuracy of the dual-frequency microwave interferometry measurement for sea surface monitoring from space / Min-Ho Ka, A. I. Baskakov // J. Electromagnetic Waves Applications. - 2015. - Vol. 29, No. 16. - P. 2199-2206. - DOI : 10.1080/09205071.2015.1062806.

4. The Bird $\AA$ Model 5000-EX RF Digital Power Meter. - Режим доступа: http://www.chuckmartin.com/category/Bird-5000-Digital -Meters-51. - Дата доступа: 19.04.16.

5. Digital Power Meter company Rohde \& Schwarz. Режим доступа:

http://www.distek.ro/en/Product/RF-Power-Meter-Rohde -and-Schwarz-NRP2-1076. - Дата доступа: 19.04.16.

6. Основные технические характеристики ваттметров компании «Меридиан». - Режим доступа: http://www.meridian-pr.ru/?c=show \&id $=671 \& \mathrm{~m}=$ catalo g. - Дата доступа: 19.04.16.

7. Пондеромоторное действие электромагнитного поля (теория и приложения) / Р. А. Валитов, Н. А. Хижняк, В. С. Жилков, [и др.] ; под ред. Р. А. Валитова. - М. : Сов радио, 1975. - 232 с.

8. Козар А. I. Електромагнітні явища в резонансних складних просторових системах малих магнітодіелектричних сфер : автореф. дис. ... д.ф.м.н. / А. І. Козар. - Харків : ХНУРЕ, 2010. - 37 с.

9. Макеева Г. С. Электродинамический анализ постоянных распространения электромагнитных волн в 3D-решетках магнитных нанопроволок в условиях магнитного резонанса в микроволновом диапазоне / Г. С. Макеева, О. А. Голованов // Радиотехника и электроника. - 2016. - T. 61, № 1. - C. 1-11. - DOI : 10.7868/S0033849415110145.

10. Електродинаміка та поширення радіохвиль. Ч.1. Основи теорії електромагнітного поля / В. М. Шокало, В. І. Правда, В. А. Усін, [та ін.] ; за ред. В. М. Шокало, В. І. Правди. - Харків : Колегіум, 2009. $286 \mathrm{c}$.

11. Гуревич А. Г. Ферриты на сверхвысоких частотах / А. Г. Гуревич. — М. : Физматгиз, 1960. 208 c.

Поступила в редакцию ? По-сле переработки ? 